\title{
Atmospheric chemistry of nitrogenous aerosols in northeastern Asia: biological sources and secondary formation
}

\author{
C. M. Pavuluri ${ }^{1}$, K. Kawamura ${ }^{1}$, and P. Q. Fu ${ }^{1, \mathrm{a}}$ \\ ${ }^{1}$ Institute of Low Temperature Science, Hokkaido University, Sapporo 060-0819, Japan \\ ${ }^{a}$ present address: LAPC, Institute of Atmospheric Physics, Chinese Academy of Sciences, Beijing 100029, China \\ Correspondence to: K. Kawamura (kawamura@lowtem.hokudai.ac.jp)
}

Received: 21 March 2015 - Published in Atmos. Chem. Phys. Discuss.: 29 April 2015

Revised: 18 August 2015 - Accepted: 23 August 2015 - Published: 2 September 2015

\begin{abstract}
To better understand the sources of nitrogenous aerosols, particularly water-soluble organic nitrogen (WSON) and water-insoluble organic nitrogen (WION), in northeastern Asia, we measured total nitrogen (TN) and water-soluble total nitrogen (WSTN) as well as nitrogen isotope ratios $\left(\delta^{15} \mathrm{~N}\right)$ of TN $\left(\delta^{15} \mathrm{~N}_{\mathrm{TN}}\right)$ and WSTN $\left(\delta^{15} \mathrm{~N}_{\mathrm{WSTN}}\right)$ in the total suspended particulate (TSP) samples collected from Sapporo, northern Japan, for a 1-year period. In general, WION was more abundant $\left(126 \pm 117 \mathrm{ng} \mathrm{m}^{-3}\right)$, whereas WSON was $89.7 \pm 80.6 \mathrm{ng} \mathrm{m}^{-3}$, accounting for $14 \pm 11 \%$ and $9.2 \pm 7.3 \%$ of $\mathrm{TN}$, respectively. WSON peaked in late autumn to winter (maximum $288 \mathrm{ng} \mathrm{m}^{-3}$ ) and WION peaked in mid-spring to early summer $\left(454 \mathrm{ng} \mathrm{m}^{-3}\right) . \delta^{15} \mathrm{~N}_{\mathrm{TN}}(21.9 \pm$ $4.1 \%$ ) and $\delta^{15} \mathrm{~N}_{\text {WSTN }}(25.8 \pm 8.2 \%$ ) showed peaks in summer with relatively high ratios in late autumn. Based on the seasonal variations in WSON and WION together with organic tracers, fossil fuel combustion and biomass burning are found to be two major sources of WSON, whereas emissions of biological particles and secondary formation by reactions of biogenic secondary organic species (carbonyls) with $\mathrm{NH}_{3}$ are suggested as an important source of WION. The seasonality of $\delta^{15} \mathrm{~N}_{\mathrm{TN}}$ and $\delta^{15} \mathrm{~N}_{\mathrm{WSTN}}$, together with the comparisons to literature values, implies that chemical aging (including gas-particle partitioning) and biomass burning are the causes of the enhanced values in summer and autumn, respectively. This study demonstrates that contributions of aerosol $\mathrm{N}$ from fossil fuel combustion and biomass burning dominate in autumn and/or winter, whereas emission of terrestrial biological particles and secondary formation from biogenic hydrocarbons and subsequent chemical aging in the atmosphere are important in spring and/or summer in northeastern Asia.
\end{abstract}

\section{Introduction}

In eastern Asia, high loading of aerosol nitrogen $(\mathrm{N})$ and its significant deposition onto the Earth surface are associated with the enhanced agricultural usage of nitrogenous fertilizer: $40 \%$ of vegetation receives nitrogen deposition in excess of $1000 \mathrm{mg} \mathrm{N} \mathrm{m}^{-2} \mathrm{yr}^{-1}$ (threshold level), and the figure is even higher $(\sim 50 \%)$ in Japan (Dentener et al., 2006; Liu et al., 2013; Morino et al., 2011). Emissions of $\mathrm{NH}_{3}$ and $\mathrm{NO}_{x}$ to the air have an impact on atmospheric chemistry, visibility impairment, human health and the Earth's climate system (Rollins et al., 2012; Vitousek et al., 1997). Furthermore, N deposition over the Earth surface has a large influence on terrestrial and aquatic ecosystems via the changes in the global biogeochemical cycles (Duce et al., 2008; Galloway et al., 2004; Kim et al., 2014). Most studies of aerosol N in eastern Asia and other regions around the world have been focused on inorganic species $\left(\mathrm{NO}_{3}^{-}\right.$and $\left.\mathrm{NH}_{4}^{+}\right)$(Dentener et al., 2006; Duce et al., 2008; Liu et al., 2013). Although organic nitrogen $(\mathrm{ON})$ represents a significant fraction (up to $80 \%$ ) of total aerosol $\mathrm{N}$ and may play a critical role in biogeochemical cycles, ON has rarely been studied (Cape et al., 2011; Matsumoto et al., 2014; Zhang et al., 2008).

Aerosol ON is comprised of a wide range of nitrogenous compounds from semivolatile amines to proteins and macromolecules (Cape et al., 2011; Laskin et al., 2009; Wang et al., 2010). In addition to biomass burning, primary sources, including biological particles emitted from soil, vegetation, pollen, bacteria and the ocean surface, are important (Cape et al., 2011; Jickells et al., 2013; Miyazaki et al., 2014; Neff et al., 2002). ON can also be produced in the atmosphere via the reactions of $\mathrm{NO}_{3}$ radical or $\mathrm{NH}_{3}$ with biogenic and/or 
anthropogenic volatile organic compounds (VOCs) followed by gas-to-particle conversion (Cornell et al., 2001; Miyazaki et al., 2014; Pratt et al., 2012). Recently, the oxidation of isoprene and monoterpenes by $\mathrm{NO}_{3}$ has been considered a substantial source of organic nitrates and secondary organic aerosols (SOAs) (Fry et al., 2009; Pratt et al., 2012; Rollins et al., 2009, 2012). Furthermore, chemical aging of SOA derived from both biogenic and anthropogenic precursors in the presence of $\mathrm{NH}_{3}$ in the gas phase and $\mathrm{NH}_{4}^{+}$salts in the aqueous phase can produce light-absorbing nitrogenous compounds (defined as brown carbon) (Bones et al., 2010; Updyke et al., 2012).

However, the relative importance of anthropogenic and biogenic emissions including biomass burning is largely unknown, and the secondary formation of $\mathrm{ON}$ has been poorly characterized (Cape et al., 2011; Jickells et al., 2013; Kanakidou et al., 2012) and thus the land-atmosphere interactions of aerosol $\mathrm{N}$ are not fully understood yet because of limited measurements of aerosol ON. Previous studies of ON have focused on water-soluble ON (WSON), but very little is known about the abundances and sources of waterinsoluble ON (WION) particularly in continental aerosols. Interestingly, WION is much more abundant (on average $\left.34.0 \mathrm{nmol} \mathrm{Nm}^{-3}\right)$ than WSON $\left(4.5 \mathrm{nmol} \mathrm{Nm}^{-3}\right)$ in aerosols from Lewes, Delaware, on the mid-Atlantic US coast (Russell et al., 2003) and marine aerosols $(55 \pm 16 \%$ of total N) over the western North Pacific (Miyazaki et al., 2011). Hence, it is of interest to investigate the seasonal variations in WSON and WION.

Here, we present total N (TN), water-soluble TN (WSTN), WSON and WION and nitrogen isotope ratios $\left(\delta^{15} \mathrm{~N}\right)$ of $\mathrm{TN}\left(\delta^{15} \mathrm{~N}_{\mathrm{TN}}\right)$ and WSTN $\left(\delta^{15} \mathrm{~N}_{\mathrm{WSTN}}\right)$ measured in ambient aerosols (TSP) collected from Sapporo, northern Japan, over a 1-year period. The isotope studies are helpful in understanding the origins and atmospheric processing of $\mathrm{N}$ (Kawamura et al., 2004; Pavuluri et al., 2010). Based on WSON and WION data together with various organic tracers, $\delta^{15} \mathrm{~N}$ values and air mass trajectories as well as the comparison with previous studies, we discuss the atmospheric chemistry of nitrogenous aerosols and their possible sources, with a major focus on WSON and WION in northeastern Asia.

\section{Materials and methods}

\subsection{Aerosol sampling}

Total suspended particulate (TSP) samples were collected from Sapporo in the western part of Hokkaido Island, northern Japan $\left(43.07^{\circ} \mathrm{N}, 141.36^{\circ} \mathrm{E}\right)$, an ideal location for collecting the air masses delivered from northeastern Asian regions: Siberia, the Russian Far East, China, and the surrounding oceans (Aggarwal and Kawamura, 2008; Yamamoto et al., 2011). The geographic details of the sampling site are described elsewhere (Pavuluri et al., 2013). TSP sampling $(n=21)$ was performed on the rooftop of the three-story building of the Institute of Low Temperature Science (ILTS), Hokkaido University, Sapporo, from 2 September 2009 to 5 October 2010 using a pre-combusted $\left(450^{\circ} \mathrm{C}, 4 \mathrm{~h}\right)$ quartz fiber filter and high-volume $\left(\sim 65 \mathrm{~m}^{3} \mathrm{~h}^{-1}\right)$ air sampler. Each sample was collected for ca. 2 consecutive weeks in order to obtain sufficient amounts of carbon for radiocarbon $\left({ }^{14} \mathrm{C}\right)$ analyses at organic molecular levels, another objective of this research. Filter samples were placed in a pre-combusted glass jar with a Teflon-lined screw cap and stored in a dark room at $-20^{\circ} \mathrm{C}$ prior to analysis.

It should be noted that aerosol samples collected on quartz fiber filters might have positive (adsorption of gaseous $\mathrm{HNO}_{3}$ and $\mathrm{NH}_{3}$ and WSON) and negative (evaporation of particulate $\mathrm{NH}_{4}^{+}$salts such as $\mathrm{NH}_{4} \mathrm{NO}_{3}$ and WSON) sampling artifacts (Matsumoto et al., 2014; Squizzato et al., 2013). Since the sampling time is long ( $\sim 2$ weeks) in this study, the evaporative loss from the particles should be more significant than the adsorbed gases by quartz fiber filter and thus the reported concentrations may be underestimated. However, the ambient temperatures encountered in Sapporo are rather low (range of averages of each sample period: -3.30 to $24.5^{\circ} \mathrm{C}$ ) (Pavuluri et al., 2015), and thus may not cause a significant evaporative loss of $\mathrm{N}$ species during the sampling period because quartz filters show a good retention for semivolatile $\mathrm{NH}_{4} \mathrm{NO}_{3}$ sampled at an air temperature up to $21^{\circ} \mathrm{C}$ and $\sim 30 \%$ at even an elevated air temperature of $35^{\circ} \mathrm{C}$ (Schaap et al., 2004). Therefore, we believe that our sampling technique does not have serious sampling artifacts even in summer.

\subsection{Chemical analyses}

\subsubsection{Determination of TN and WSTN and their N isotope ratios}

TN and WSTN contents and their isotope ratios $\left(\delta^{15} \mathrm{~N}_{\mathrm{TN}}\right.$ and $\delta^{15} \mathrm{~N}_{\mathrm{WSTN}}$, respectively) in TSP samples were determined using an elemental analyzer (EA) (Carlo Erba NA 1500) and an isotope ratio mass spectrometer (IRMS) (Finnigan MAT Delta Plus), respectively, as described elsewhere (Kawamura et al., 2004; Pavuluri et al., 2010). An aliquot of filter sample $(1.8 \mathrm{~cm}$ in diameter disc $\times 3)$ was extracted for WSTN with $\sim 15 \mathrm{~mL}$ Milli Q water $(>18.3 \mathrm{M} \Omega$ ) under ultrsonication for $20 \mathrm{~min}$ and filtrated with a syringe filter (GL Sciences Chromatodisc Type A, $0.45 \mu \mathrm{m})$. The extracts were adjusted to $\mathrm{pH} 8-9$ with $\sim 0.5 \mathrm{~mL}$ of $0.05 \mathrm{M} \mathrm{KOH}$, concentrated to dryness using a rotary evaporator under vacuum and then redissolved in $200 \mu \mathrm{L}$ Milli Q water. An aliquot of filter sample $(1.0 \mathrm{~cm}$ diameter disc for $\mathrm{TN}$ and $50 \mu \mathrm{L}$ of water extract, a subsample of the $200 \mu \mathrm{L}$ redissolved extract, adsorbed onto $\sim 20 \mathrm{mg}$ of pre-combusted Chromosorb for WSTN) was placed in a pre-cleaned tin cup and introduced into the EA. The resulting $\mathrm{N}_{2}$ gas was measured with a thermal conductivity detector in the EA and transferred to IRMS 
via an interface (ConFlo II) for ${ }^{15} \mathrm{~N} /{ }^{14} \mathrm{~N}$ measurement. The blank levels in TN measurements are found to be $0.0 \mu \mathrm{g} \mathrm{N}$. The analytical uncertainties (i.e., relative standard deviation) in a single set of duplicate analyses of filter samples were within $6 \%$ for TN, $3 \%$ for WSTN, $0.28 \%$ for $\delta^{15} \mathrm{~N}_{\mathrm{TN}}$ and $1.34 \%$ for $\delta^{15} \mathrm{~N}_{\mathrm{WSTN}}$. The detection limit of the EA determined by the sensitivity of the detector is $0.4 \mu \mathrm{g} \mathrm{N}$ (Neiuwenhuize et al., 1994).

We also measured WSTN using a total organic carbon (TOC)/total nitrogen (TN) analyzer (Shimadzu TOC-Vcsh), as reported by Miyazaki et al. (2011). Briefly, an aliquot of filter $(1.4 \mathrm{~cm}$ in diameter disc) was extracted with $10 \mathrm{~mL}$ Milli Q water under ultrasonication for $20 \mathrm{~min}$. The extracts were filtered with a syringe filter (GL Sciences Chromatodisc Type A, $0.45 \mu \mathrm{m}$ ) and then injected into a TOC/TN analyzer. The analytical uncertainty in duplicate analyses of filter samples was within $5 \%$.

Concentrations of WSTN measured by the EA are lower by $23 \pm 5 \%$ than those measured by the TOC/TN analyzer. The difference was significant when the concentration of WSTN was greater than $0.5 \mu \mathrm{g} \mathrm{m}^{-3}$. The difference may have arisen from different combustion temperatures $\left(1400^{\circ} \mathrm{C}\right.$ for the EA vs. $680^{\circ} \mathrm{C}$ for the TOC/TN analyzer) and different procedures. We consider that the WSTN measured by the EA may be underestimated due to possible evaporative loss of $\mathrm{N}$ species such as $\mathrm{NH}_{3}$ and $\mathrm{HNO}_{3}$ during the concentration step and/or the loss of $\mathrm{N}$ species that remain on glass walls. In fact, if the evaporative loss of $\mathrm{N}$ species, e.g., $\mathrm{NH}_{3}$, is significant, $\delta^{15} \mathrm{~N}$ of the remaining WSTN should vary significantly, proportionally to the loss of WSTN because of isotopic fractionation caused by an $\mathrm{NH}_{4}^{+}-\mathrm{NH}_{3}$ exchange (phase partitioning) reaction (Hoefs, 2009). Under equilibrium conditions, $\delta^{15} \mathrm{~N}$ values of $\mathrm{NH}_{4}^{+}$become higher than those of

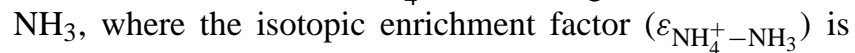
estimated to be $+33 \%$ (Heaton et al., 1997). However, $\delta^{15} \mathrm{~N}_{\text {WSTN }}$ did not show any abnormal deviation in its temporal trend, which is comparable to that of $\delta^{15} \mathrm{~N}_{\mathrm{TN}}$ (see Fig. 2b), suggesting that the evaporative loss of $\mathrm{N}$ species and thus the impact of WSTN loss on its $\delta^{15} \mathrm{~N}$ are not important. Here, we use WSTN measured by the TOC/TN analyzer to minimize the uncertainties in the estimation of WSON and WION.

\subsubsection{Measurements of inorganic ions}

Details of the measurements of inorganic ionic species such as $\mathrm{NO}_{3}^{-}, \mathrm{NH}_{4}^{+}$and methanesulfonate $\left(\mathrm{MSA}^{-}, \mathrm{CH}_{3} \mathrm{SO}_{3}^{-}\right.$) are described elsewhere (Pavuluri et al., 2015). Briefly, an aliquot of filter sample was extracted with Milli Q water under ultrasonication and filtrated with a syringe filter (GL Sciences Chromatodisc Type A, $0.45 \mu \mathrm{m}$ ). The filtrates were then injected into an ion chromatograph (761 Compact IC, Metrohm). A calibration curve was prepared with a set of authentic standards to calculate the concentrations for the samples. The analytical precision was within $4 \%$.

\subsubsection{Estimation of WSON and WION}

Amounts of inorganic $\mathrm{N}$ (IN), i.e., the sum of $\mathrm{NO}_{3}^{-}-\mathrm{N}$ and $\mathrm{NH}_{4}^{+}-\mathrm{N}$, were calculated from the concentrations of $\mathrm{NO}_{3}^{-}$ and $\mathrm{NH}_{4}^{+}$ions (Pavuluri et al., 2015). The amounts of ON, WSON and WION were estimated by the following equations (Miyazaki et al., 2011):

$$
\begin{aligned}
\mathrm{ON} & =\mathrm{TN}-\mathrm{IN} \\
\mathrm{WSON} & =\mathrm{WSTN}-\mathrm{IN} \\
\mathrm{WION} & =\mathrm{TN}-\mathrm{WSTN} .
\end{aligned}
$$

Using the propagating errors of each parameter, the precision of ON, WSON and WION was estimated to be within $8 \%$.

\subsubsection{Measurements of organic tracers}

Organic tracers such as hopanes, isoprene- and monoterpeneoxidation products were determined using a capillary gas chromatograph (Hewlett-Packard 6890) coupled to a mass spectrometer (Hewlett-Packard 5973) (GC/MS) as described elsewhere (Fu et al., 2010). Briefly, organic tracer compounds were extracted from the filter samples with dichloromethane/methanol $(2: 1 ; \mathrm{v} / \mathrm{v})$ under ultrasonication. The hydroxyl and carboxyl functional groups were derivatized to trimethylsilyl (TMS) ethers and esters, respectively, with $50 \mu \mathrm{L}$ of N,O-bis(trimethylsilyl)triflouroacetamide (BSTFA) containing $1 \%$ trimethylsilyl chloride and $10 \mu \mathrm{L}$ of pyridine. The TMS derivatives were then measured using a GC/MS. The analytical errors in duplicate analyses were less than $10 \%$.

All the data reported here are corrected for the field blank collected in each season.

\section{Results and discussion}

\subsection{Source regions of Sapporo aerosols}

Ten-day backward air mass trajectories arriving in Sapporo at $500 \mathrm{~m}$ above the ground level (a.g.l.) were computed for every $48 \mathrm{~h}$ during each sample period using the HYSPLIT model (Draxler and Rolph, 2012) and are plotted in Fig. 1. The trajectories show that the air masses mostly originated from Siberia and passed over northeastern Asian regions and the Sea of Japan during autumn, winter and spring (Fig. 1). In summer, they originated from the East China Sea and/or western North Pacific passing over the coastal region and/or Honshu of Japan (Fig. 1). The air parcels mostly traveled at a height of less than 2000 ma.g.l. in all seasons, and hence there should be significant advection of these parcels from distant source regions to the receptor site.

In fact, the radiocarbon analyses showed that the percentage of modern carbon (pMC) of total carbon and watersoluble organic carbon in our aerosols started to increase 


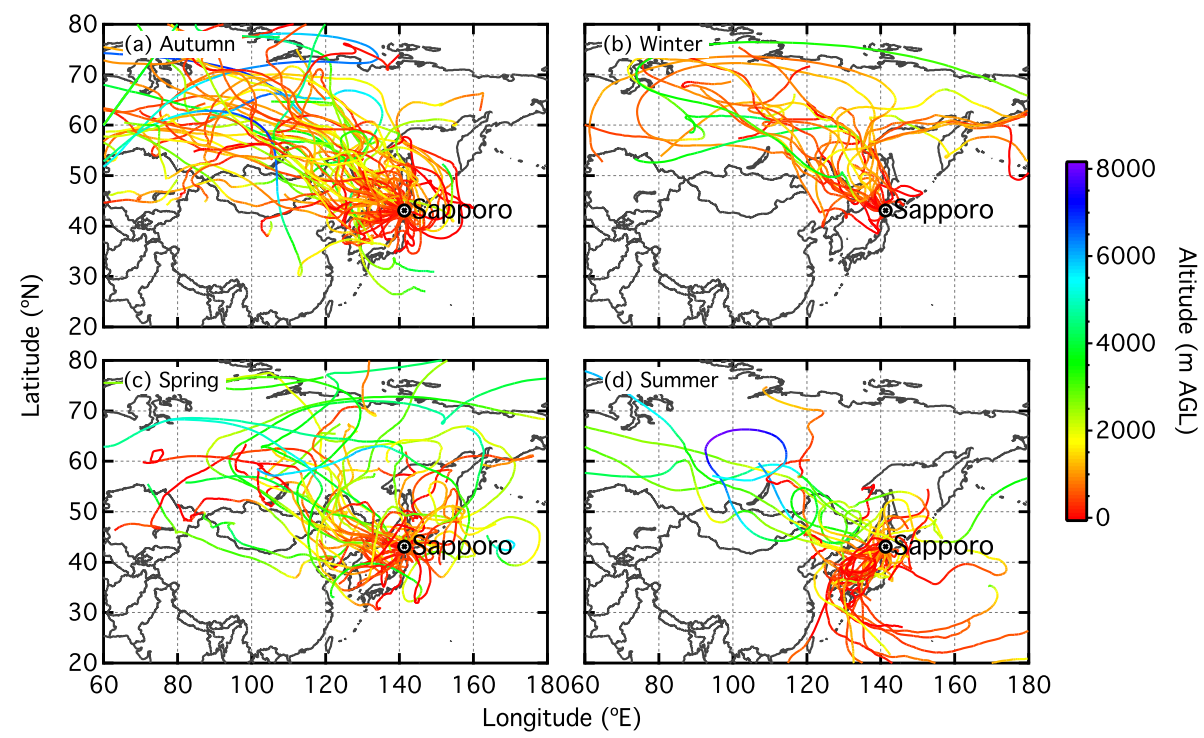

Figure 1. Plots of 10-day backward air mass trajectories arriving over Sapporo at $500 \mathrm{~m}$ a.g.l.

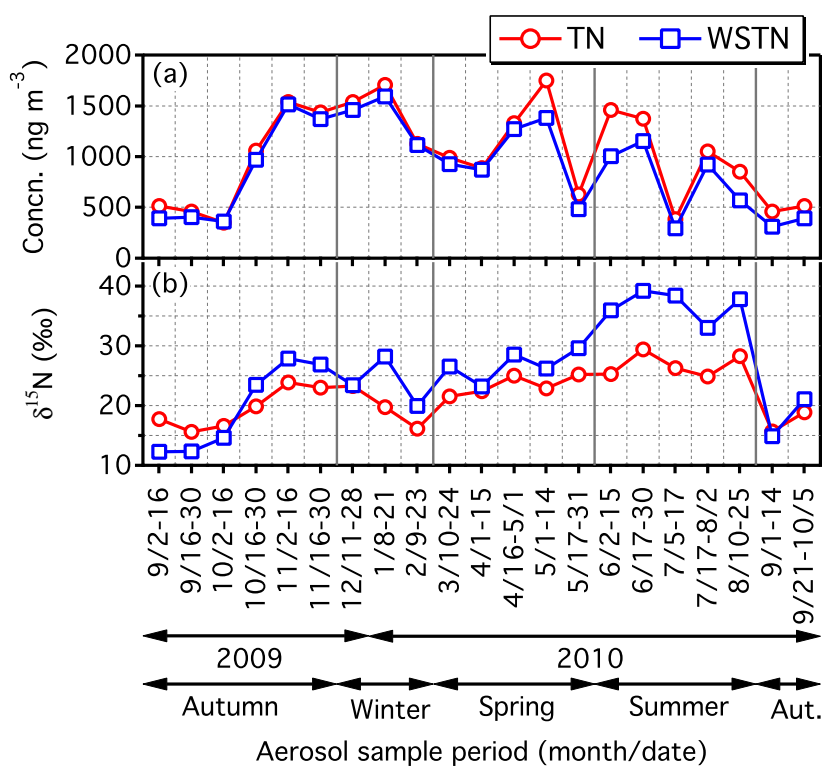

Figure 2. Seasonal variations in (a) concentrations of $\mathrm{TN}$ and WSTN and (b) $\mathrm{N}$ isotope ratios of $\mathrm{TN}\left(\delta^{15} \mathrm{~N}_{\mathrm{TN}}\right)$ and WSTN $\left(\delta^{15} \mathrm{~N}_{\text {WSTN }}\right)$.

from mid- to late winter onwards (Pavuluri et al., 2013), although the growing season starts in May in Hokkaido when daily average temperatures are $\geq 10^{\circ} \mathrm{C}$ (Toma et al., 2011). Because the contribution of modern carbon from local vegetation is unlikely in winter, such an increase in pMC during winter has been mainly attributed to the contributions of biomass burning aerosols via long-range transport from eastern Asia (Pavuluri et al., 2013). In addition, temporal variations in crustal metals, e.g., Al, $\mathrm{Ca}$ and $\mathrm{Fe}$, in Sapporo aerosols are consistent with those of TSP from winter to mid- summer, with a peak in early spring, indicating a significant atmospheric transport of Asian dust from arid regions in Mongolia and China (Pavuluri et al., 2015). Therefore, we consider that the Sapporo aerosols were probably mainly influenced by air masses from distant sources that were transported a long way over northeastern Asia. However, the characteristics and seasonal variations in Sapporo aerosols could reflect the regional scenario and we do not preclude an impact from the local sources during the campaign.

\subsection{Total nitrogen (TN) and water-soluble total nitrogen (WSTN)}

Concentrations of TN and WSTN ranged from 348 to $1750 \mathrm{ng} \mathrm{m}^{-3}$ (average $1020 \pm 466 \mathrm{ng} \mathrm{m}^{-3}$ ) and 293 to $1520 \mathrm{ng} \mathrm{m}^{-3}\left(893 \pm 443 \mathrm{ng} \mathrm{m}^{-3}\right)$, respectively, in Sapporo aerosols during the study period $(n=21)$. The mass fractions of TN in TSP ranged from 1.20 to $8.66 \%$ (average $3.81 \pm 2.28 \%$ ). As shown in Fig. 2a, although the temporal trends in TN and WSTN did follow a seasonal pattern, except for few samples, their increasing and decreasing trends are not quite distinct from season to season. However, on average, they were higher in winter, followed by spring, summer and autumn (Table 1). Similarly, TN / TSP mass ratios did not show any clear temporal trend during the study period but showed a drastic increase from mid-autumn $(1.31 \%)$ to winter $(8.66 \%)$. TN / TSP mass ratios (average $3.8 \%$, range $1.2-$ $8.7 \%$ ) observed in Sapporo aerosols during the campaign are lower than those (average $5 \%$, range 2-15\%) reported for urban aerosols from Tokyo (Kawamura et al., 1995), where anthropogenic source contributions are expected to be the major source. However, wintertime TN / TSP mass ratios in Sapporo aerosols $(\geq 7.8 \%)$ are close to that reported from urban Tokyo, suggesting that the contributions from anthropogenic 
Table 1. Seasonal and annual averages with standard deviation of the concentrations of nitrogenous components and ${ }^{15} \mathrm{~N}$ isotope ratios of TN and WSTN in atmospheric aerosol (TSP) samples collected from 2 September 2009 to 5 October 2010 in Sapporo, northern Japan.

\begin{tabular}{lccccc}
\hline Component & Autumn $(n=8)$ & $\begin{array}{c}\text { Winter }(n=3) \\
\text { Concentrations }\left(\mathrm{ng} \mathrm{m}^{-3}\right)\end{array}$ & $\begin{array}{c}\text { Spring }(n=5) \\
\text { Summer }(n=5)\end{array}$ & Annual $(n=19)$ \\
\hline $\mathrm{TN}$ & $790 \pm 480$ & $1456 \pm 298$ & $1116 \pm 434$ & $1023 \pm 433$ & $1074 \pm 454$ \\
$\mathrm{WSTN}$ & $714 \pm 496$ & $1388 \pm 247$ & $986 \pm 356$ & $789 \pm 351$ & $950 \pm 427$ \\
$\mathrm{NO}_{3}^{-}-\mathrm{N}$ & $284 \pm 120$ & $362 \pm 55.2$ & $395 \pm 182$ & $73.8 \pm 24.1$ & $279 \pm 172$ \\
$\mathrm{NH}_{4}^{+}-\mathrm{N}$ & $338 \pm 347$ & $896 \pm 97.2$ & $511 \pm 191$ & $647 \pm 310$ & $576 \pm 314$ \\
$\mathrm{ON}$ & $168 \pm 77.1$ & $198 \pm 186$ & $212 \pm 221$ & $302 \pm 149$ & $220 \pm 157$ \\
$\mathrm{WSON}$ & $91.6 \pm 73.6$ & $130 \pm 139$ & $84.7 \pm 99.5$ & $67.8 \pm 39.8$ & $96.0 \pm 81.9$ \\
$\mathrm{WION}$ & $77.5 \pm 50.9$ & $68.4 \pm 51.3$ & $130 \pm 141$ & $234 \pm 144$ & $125 \pm 123$ \\
\hline \multicolumn{7}{c}{ Isotope ratios $(\%)$} \\
\hline$\delta^{15} \mathrm{~N}_{\mathrm{TN}}$ & $18.91 \pm 3.17$ & $19.72 \pm 3.56$ & $23.42 \pm 1.63$ & $26.82 \pm 1.95$ & $22.47 \pm 3.98$ \\
$\delta^{15} \mathrm{~N}_{\mathrm{WSTN}}$ & $19.17 \pm 6.45$ & $23.84 \pm 4.13$ & $26.82 \pm 2.46$ & $36.88 \pm 2.46$ & $26.71 \pm 8.16$ \\
\hline
\end{tabular}

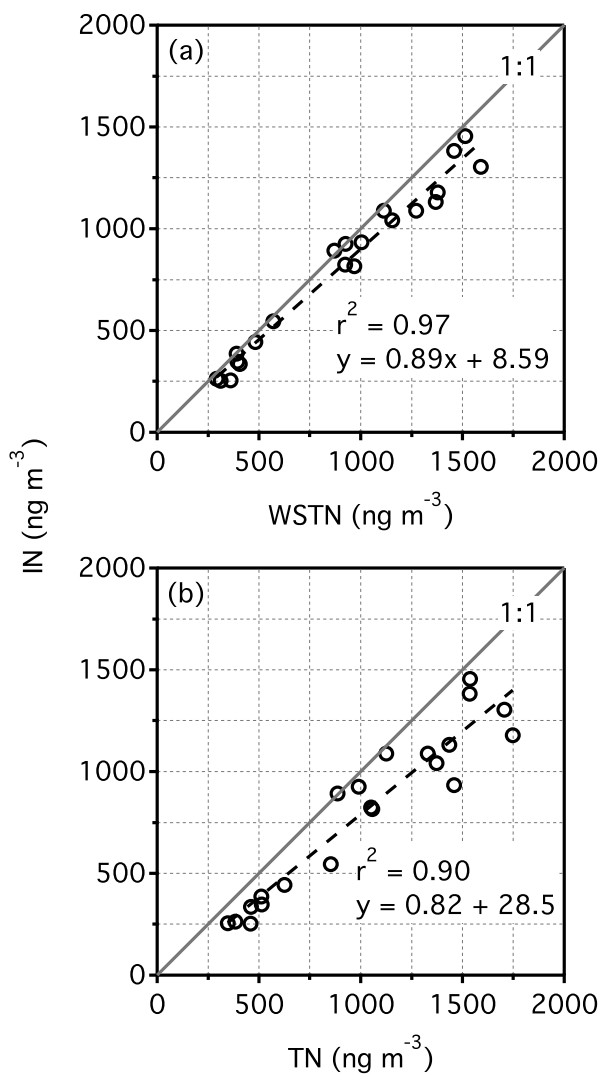

Figure 3. Linear relations of $\mathrm{IN}$ (sum of $\mathrm{NO}_{3}^{-}-\mathrm{N}$ and $\mathrm{NH}_{4}^{+}-\mathrm{N}$ ) to (a) WSTN and (b) TN.

sources such as fossil fuel combustion may be significant in winter.

As seen from Fig. 3, WSTN contains mostly IN (i.e., $\sum \mathrm{NO}_{3}^{-}-\mathrm{N}+\mathrm{NH}_{4}^{+}-\mathrm{N}$ ) (range 70.8-100\%, average $89.7 \pm$ $7.74 \%$ ), whereas TN consists of a significant amount of ON (average $22.7 \pm 17.7 \%$, maximum $44.7 \%$ ), which ranged from below the detection limit (BDL) to $569 \mathrm{ng} \mathrm{m}^{-3}(215 \pm$ $150 \mathrm{ng} \mathrm{m}^{-3}$ ) during the study period. High abundances of $\mathrm{ON}$ in TN rather than WSTN indicate that WION is significant in Sapporo aerosols. Furthermore, WSTN showed a stronger linear relation with IN $\left(r^{2}=0.97\right)$ than that $\left(r^{2}=0.90\right)$ between TN and IN in Sapporo aerosols (Fig. 3). Such deviation in the linearity suggests that the origins and/or secondary formation processes of WION (i.e., TN - WSTN) may be different from that of WSTN (including WSON). Therefore, it is apparent that the atmospheric loading and impacts of aerosol $\mathrm{N}$ in northeastern Asia is significantly influenced by the sources and seasonality of $\mathrm{ON}$.

\subsection{Water-soluble organic nitrogen (WSON) and water-insoluble organic nitrogen (WION)}

\subsubsection{Concentrations and mass fractions in TN}

Concentrations of WSON and WION in Sapporo aerosols ranged from the $\mathrm{BDL}$ to $288 \mathrm{ng} \mathrm{m}^{-3}$ and from the BDL to $454 \mathrm{ng} \mathrm{m}^{-3}$, respectively. On average, WION is more abundant $\left(126 \pm 117 \mathrm{ng} \mathrm{m}^{-3}\right)$ than WSON $\left(89.7 \pm 80.6 \mathrm{ng} \mathrm{m}^{-3}\right)$. Although the temporal variations did not show any clear seasonal pattern, WSON maximized in late autumn to midwinter, whereas WION peaked in mid-spring to early summer (i.e., in growing season) (Fig. 4a). Furthermore, seasonally averaged concentrations of WSON are higher in winter, followed by autumn, spring and summer, whereas those of WION are higher in summer, followed by spring, and much lower in autumn and winter, although the seasonal differences are not statistically significant (Table 1). On average, the mass fraction of WION in $\mathrm{TN}$ is $13.9 \pm 11.1 \%$ (range $\mathrm{BDL}-33.1 \%$ ) and the $\mathrm{WSON} / \mathrm{TN}$ ratio is $9.13 \pm 7.29 \%$ (BDL-30.2\%) during the study period. Temporal variations in the mass fractions of WSON and WION in TN (Fig. 4b) are similar to those of the concentrations (Fig. 4a). 
Table 2. Concentrations of water-soluble organic nitrogen (WSON) and the mass fractions of WSON in water-soluble total nitrogen (WSTN) in Sapporo aerosols together with those in atmospheric aerosols from different sites around the world.

\begin{tabular}{|c|c|c|c|c|c|}
\hline Location & Study period & Aerosol size & WSON $\left(\mathrm{ng} \mathrm{m}^{-3}\right)$ & WSON/WSTN (\%) & Reference \\
\hline \multicolumn{6}{|c|}{ Urban sites } \\
\hline Sapporo, Japan & September 2009 to October 2010 & TSP & $89.7 \pm 80.6$ & $10.5 \pm 7.5$ & This study \\
\hline Davis, California & August 1997 to July 1998 & $\mathrm{PM}_{2.5}$ & $265 \pm 190$ & 23 & $\begin{array}{l}\text { Zhang } \\
\text { et al. (2002) }\end{array}$ \\
\hline Kofu, Japan & August 2009 to January 2013 & $\mathrm{PM}_{10}^{\mathrm{a}}$ & 221 & $\sim 14$ & $\begin{array}{l}\text { Matsumoto } \\
\text { et al. (2014) }\end{array}$ \\
\hline \multicolumn{6}{|c|}{ Forest sites } \\
\hline Rondônia, Brazil & March-May 1999 & $\mathrm{PM}_{10}$ & $49 \pm 64.4$ & $45 \pm 35$ & $\begin{array}{l}\text { Mace } \\
\text { et al. (2003a) }\end{array}$ \\
\hline Rondônia, Brazil & September-October $1999^{\mathrm{b}}$ & $\mathrm{PM}_{10}$ & $854 \pm 938$ & $43 \pm 31$ & $\begin{array}{l}\text { Mace } \\
\text { et al. (2003a) }\end{array}$ \\
\hline Sapporo, Japan & June 2009 to December 2011 & TSP & $157 \pm 127$ & $20 \pm 11$ & $\begin{array}{l}\text { Miyazaki } \\
\text { et al. (2014) }\end{array}$ \\
\hline Fujiyoshida, Japan & August 2009 to January 2013 & $\mathrm{PM}_{10}^{\mathrm{a}}$ & 101 & $\sim 11$ & $\begin{array}{l}\text { Matsumoto } \\
\text { et al. (2014) }\end{array}$ \\
\hline \multicolumn{6}{|c|}{ Coastal sites } \\
\hline Erdemli, Turkey & March-May 2000 & TSP & $406 \pm 588$ & $\sim 26 \pm 28$ & $\begin{array}{l}\text { Mace } \\
\text { et al. }(2003 c)\end{array}$ \\
\hline Crete, Greece & 2005-2006 & $\mathrm{PM}_{10}^{\mathrm{a}}$ & $\sim 239$ & 13 & $\begin{array}{l}\text { Violaki and } \\
\text { Mihalopoulos } \\
\text { (2010) }\end{array}$ \\
\hline Qingdao, China & March-April 2006 & TSP & $2520 \pm 1760$ & $\sim 20$ & Shi et al. (2010) \\
\hline \multicolumn{6}{|c|}{ Oceanic sites } \\
\hline Yellow $\mathrm{Sea}^{\mathrm{c}}$ & March 2005 & TSP & $2860 \pm 1780$ & $\sim 17$ & Shi et al. (2010) \\
\hline Yellow Sea ${ }^{c}$ & April 2006 & TSP & $1220 \pm 812$ & $\sim 17$ & Shi et al. (2010) \\
\hline South China Sea ${ }^{c}$ & April 2005 & TSP & $910 \pm 280$ & $\sim 34$ & Shi et al. (2010) \\
\hline East China $\mathrm{Sea}^{\mathrm{c}}$ & September-October 2002 & $\mathrm{TSP}^{\mathrm{a}}$ & $756 \pm 504$ & $\sim 24$ & $\begin{array}{l}\text { Nakamura } \\
\text { et al. (2006) }\end{array}$ \\
\hline $\begin{array}{l}\text { East China Sea and western } \\
\text { North Pacific }\end{array}$ & March 2004 & $\mathrm{TSP}^{\mathrm{a}}$ & $224 \pm 266$ & $\sim 10$ & $\begin{array}{l}\text { Nakamura } \\
\text { et al. (2006) }\end{array}$ \\
\hline Cape Grim, Australia & November-December 2000 & TSP & $50.4 \pm 79.8$ & $\sim 21$ & $\begin{array}{l}\text { Mace } \\
\text { et al. (2003b) }\end{array}$ \\
\hline Cape Grim, Australia & November-December 2000 & TSP & $13.0 \pm 13.3$ & $\sim 25$ & $\begin{array}{l}\text { Mace } \\
\text { et al. (2003b) }\end{array}$ \\
\hline Oahu, Hawaii & July-August 1998 & $\mathrm{PM}_{10}$ & $46.2 \pm 28$ & $\sim 33$ & $\begin{array}{l}\text { Cornell } \\
\text { et al. (2001) }\end{array}$ \\
\hline Western North Pacific & August-September 2008 & TSP & $\sim 17.5$ & & $\begin{array}{l}\text { Miyazaki } \\
\text { et al. (2011) }\end{array}$ \\
\hline
\end{tabular}

${ }^{\mathrm{a}}$ Total of fine- and coarse-mode particles. ${ }^{\mathrm{b}}$ Dry (biomass burning) season. ${ }^{\mathrm{c}}$ Asian outflow region.

\subsubsection{Comparisons with previous studies from different locations}

As seen from Table 2, the average concentration of WSON in Sapporo aerosols is lower than that reported in urban aerosols from Davis, California, and Kofu, Japan, as well as from coastal sites: Erdemli in Turkey, Crete in Greece, and Qingdao in China. It is also lower than that reported in the forest aerosols collected from Rondônia, Brazil during an intensive biomass burning period (dry season) (Mace et al., 2003a) and from Sapporo, Japan, and lower than in the marine aerosols over the Asian outflow regions: the Yellow Sea, South China Sea and the western North Pacific (Table 2). In contrast, the average concentration of WSON in Sapporo aerosols is comparable to that of forest aerosols from Fujiyoshida, Japan, but higher than that from Rondônia, Brazil, during the wet season. It is also higher than that of the marine aerosols from pristine oceanic regions: Cape Grim, Australia (Mace et al., 2003b), and Oahu, Hawaii (Cornell et al., 2001), and over the western North Pacific (Miyazaki et al., 2011) (Table 2). In addition, the higher end (maximum $288 \mathrm{ng} \mathrm{m}^{-3}$ ) of WSON is comparable to average WSON concentration reported in 

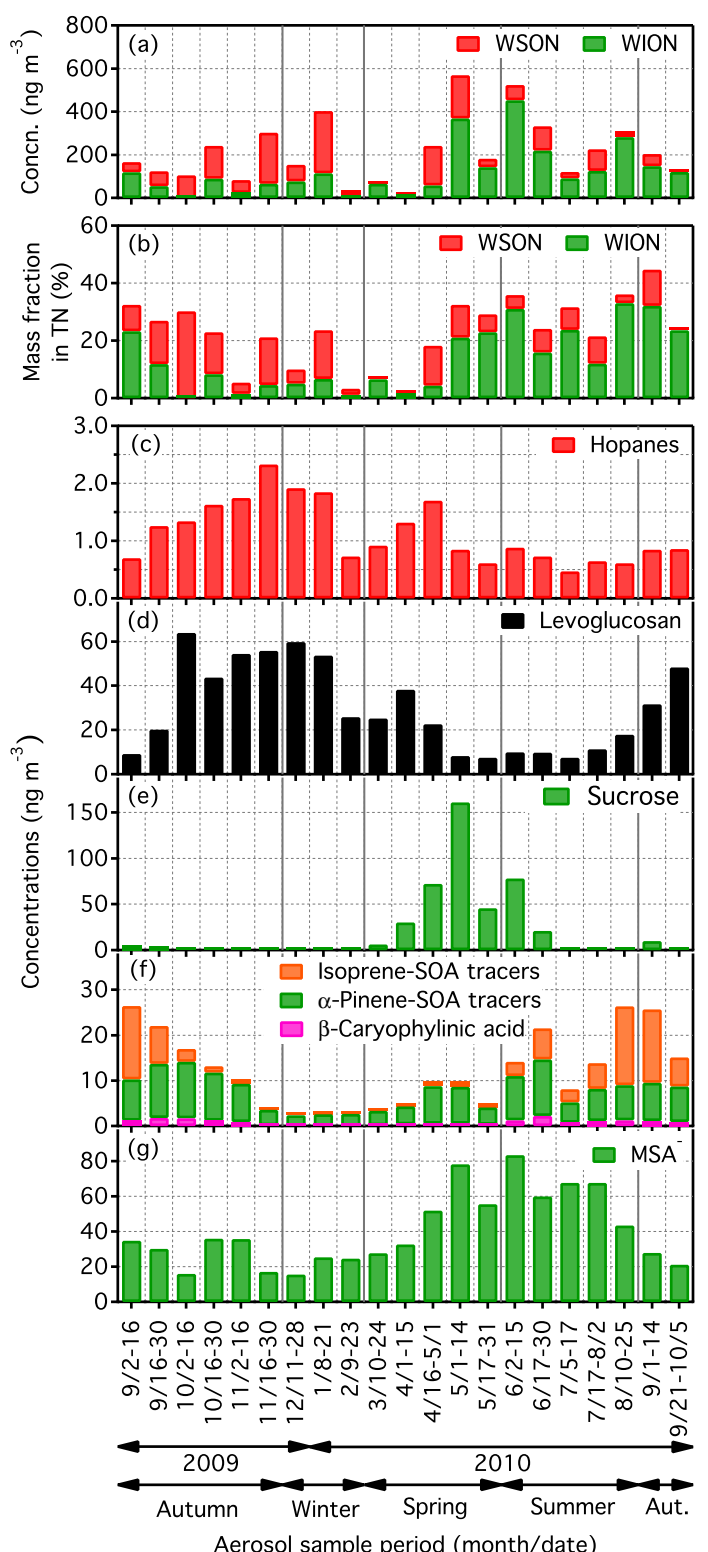

Figure 4. Seasonal variations in (a) concentrations of WSON and WION, (b) mass fractions of WSON and WION in $\mathrm{TN}$, and (c)-(e) concentrations of organic molecular tracers and $\mathrm{MSA}^{-}$in Sapporo aerosols. Concentrations of hopanes are the sum of the concentrations of $\mathrm{C}_{27}-\mathrm{C}_{32}$ hopanoid hydrocarbons. Concentrations of isoprene-SOA tracers are the sum of the concentrations of 2-methylglyceric acid, cis2-methyl-1,3,4-trihydroxy-1-butene, 3-methyl-2,3,4-trihydroxy-1butene, trans-2-methyl-1,3,4-trihydroxy-1-butene, 2-methylthreitol and 2-methylerythritol, whereas concentrations of $\alpha$-pinene-SOA tracers are the sum of the concentrations of 3-hydroxyglutaric, pinonic, pinic and 3-methyl-1,2,3-butanetricarboxylic acids. The data of organic molecular tracers are from Pavuluri et al. (2013) and $\mathrm{MSA}^{-}$is from Pavuluri et al. (2015). urban aerosols from Davis, California, and Kofu, Japan, and in coastal urban aerosols from Crete, Greece (Table 2). However, the average mass fraction of WSON in WSTN in Sapporo aerosols is found to be comparable or close to those reported for urban aerosols from Kofu, Japan, coastal urban aerosols from Crete, Greece, forest aerosols from $\mathrm{Fu}-$ jiyoshida, Japan, and the marine aerosols over the Yellow Sea, China Sea and western North Pacific (Table 2).

Higher concentrations of WSON reported for urban aerosols from Davis, California, during late fall and winter are attributed to increased amounts of atmospheric liquid water, which promote a partition of gaseous WSON to particles (Zhang et al., 2002). In Kofu and Fujiyoshida (forest site), Japan, emissions from combustion sources including biomass burning and plant-derived particles as well as secondary formation through the reaction of $\mathrm{NO}_{2}$ with volatile organics are considered potential sources of WSON (Matsumoto et al., 2014). In the Mediterranean atmosphere, atmospheric dust from north Africa was expected to be a dominant source of WSON at Erdemli, Turkey (Mace et al., 2003c), whereas in Crete, Greece, fossil fuel combustion and biomass burning are also considered (Violaki and Mihalopoulos, 2010). Over the marginal seas of China (Asian outflow region; Qingdao, the Yellow Sea and Sea of China) anthropogenic sources are considered to be the dominant origin of WSON, with minor contributions from marine and crustal sources (Nakamura et al., 2006; Shi et al., 2010). In the forest aerosols from Sapporo, Japan, emissions of biological particles are considered to be a major source of WSON in autumn, whereas secondary formation of WSON from biogenic hydrocarbons is considered to be the dominant source in summer (Miyazaki et al., 2014).

On the other hand, the average concentration of WION $\left(126 \pm 117 \mathrm{ng} \mathrm{m}^{-3}\right)$ found in Sapporo aerosols is comparable to that $\left(112 \pm 61 \mathrm{ng} \mathrm{m}^{-3}\right)$ reported in the marine aerosols over the western North Pacific, where the sea-to-air emissions, as well as the secondary production via the reactions of gaseous hydrocarbons with $\mathrm{NH}_{3}$, are considered to be the major sources (Miyazaki et al., 2011). In addition, the higher end (maximum $454 \mathrm{ng} \mathrm{m}^{-3}$ ) of WION in Sapporo aerosols is comparable to the average WION $\left(476 \mathrm{ng} \mathrm{m}^{-3}\right)$ reported in the coastal aerosols from Lewes, Delaware, where biological and mineral particles are expected as a major source (Russell et al., 2003).

Therefore, we consider that WSON in Sapporo aerosols may be mainly derived from anthropogenic emissions including biomass burning, although emissions from biological sources and secondary formation from gaseous hydrocarbon precursors cannot be excluded. Meanwhile, WION may originate from emissions of biological particles and secondary formation from biogenic hydrocarbons. We further examine the possible contributions from such sources in the following section based on comparisons between them and the source tracers. 

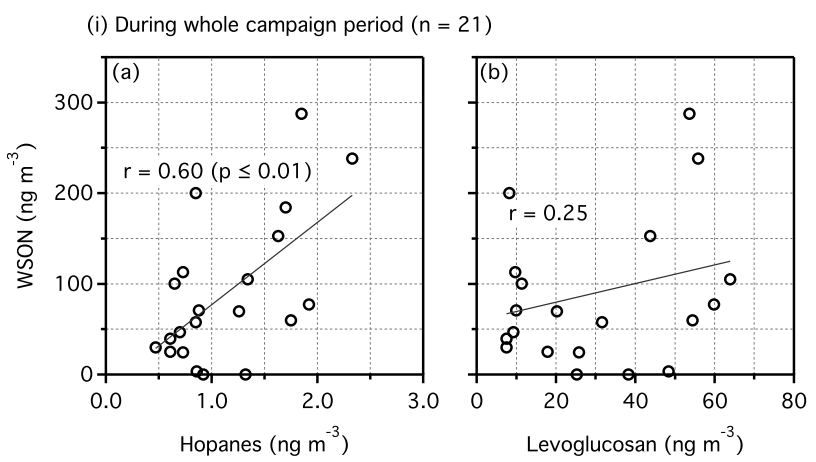

(ii) During spring and summer $(\mathrm{n}=10)$
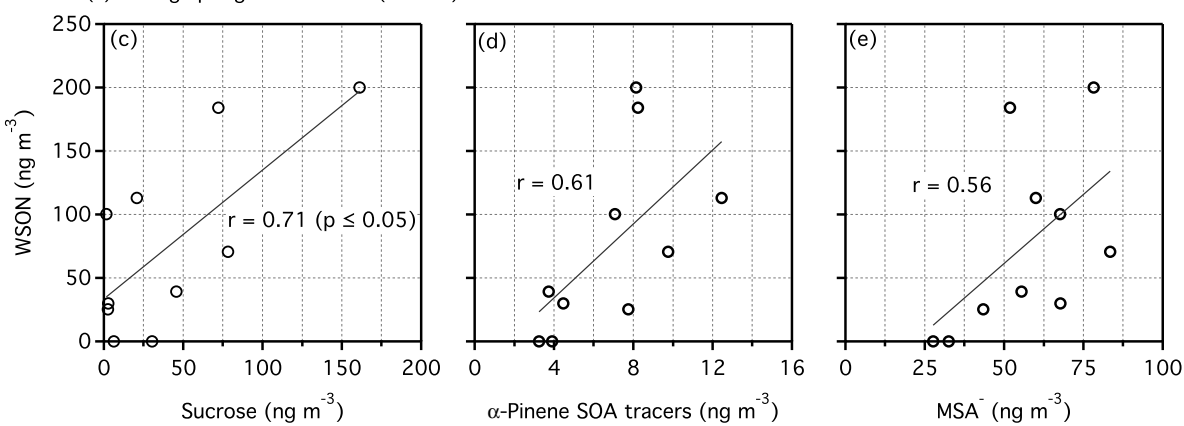

Figure 5. Linear relations of WSON with (a) hopanes $\left(\mathrm{C}_{27}-\mathrm{C}_{32}\right.$ hopanoid hydrocarbons) and (b) levoglucosan during the campaign period $(n=21)$ and with (c) sucrose, (d) $\alpha$-pinene-SOA tracers (sum of 3-hydroxyglutaric, pinonic, pinic and 3-methyl-1,2,3-butanetricarboxylic acids), and (e) $\mathrm{MSA}^{-}$in spring and summer $(n=10)$ in Sapporo aerosols.

\subsection{Comparisons of WSON and WION with organic tracers}

\subsubsection{Possible sources of WSON}

The temporal trend in WSON is found to be somewhat similar to that of hopanes $\left(\mathrm{C}_{27}-\mathrm{C}_{32}\right.$ hopanoid hydrocarbons), specific biomarkers of petroleum and coal (Schauer et al., 2002), particularly in autumn and wintertime Sapporo aerosols (Fig. 4c). Furthermore, WSON showed a linear relationship with hopanes with moderate but significant correlation during the campaign (Fig. 5a). On the other hand, the temporal variation in WSON from mid-autumn to midwinter is somewhat similar to that of levoglucosan (Fig. 4d), a tracer for biomass burning (Simoneit, 2002), and showed a weak linear relation throughout the campaign (Fig. 5b). Contributions of WSON to TN are higher in the above seasons (Fig. 4b). In contrast, WSON was abundant in few spring (from mid-April to mid-May) and summer (late June and late July) samples (Fig. 4a), despite the lower levels of both hopanes and levoglucosan throughout the spring and summer (Fig. 4c, d). The lower levels of levoglucosan in spring and summer, and thus a weak correlation of WSON with levoglucosan during the campaign, was probably caused, in part, by the decomposition of levoglucosan (Hoffmann et al., 2010) because contributions of biomass burning emissions to Sap- poro aerosols were considered to be significant during these periods (Pavuluri et al., 2015).

The temporal trend in WSON from late spring to early summer (Fig. 4a) is similar to that of sucrose (Fig. 4e), which is a tracer of pollens emitted from terrestrial higher plants (Fu et al., 2012). The seasonal trend in WSON (Fig. 4a) is also similar to those of biogenic secondary organic aerosols (SOA), i.e., $\alpha$-pinene-SOA tracers (Kleindienst et al., 2007), and $\mathrm{MSA}^{-}$in late spring to early autumn (Fig. 4f, g). $\mathrm{MSA}^{-}$ is produced in the atmosphere by photochemical oxidation of dimethyl sulfide (DMS) (Bates et al., 1992), which is emitted from terrestrial higher plants (Geng and $\mathrm{Mu}, 2006$ ), soil in forests (Yi et al., 2010) and phytoplankton bloom in oceans (Bates et al., 1992). Therefore, $\mathrm{MSA}^{-}$can be considered a tracer to understand the importance of secondary production of WSON (and WION) from biogenic organics, although neither DMS nor MSA ${ }^{-}$contain nitrogen. Interestingly, WSON showed a linear relation with sucrose $(r=0.71, p \leq 0.05), \alpha$-pinene SOA tracers and $\mathrm{MSA}^{-}$during spring and summer (Fig. 5c-e). In fact, the Spearman's rank correlations of WSON with $\alpha$-pinene SOA tracers $(r=$ $0.71)$ and $\mathrm{MSA}^{-}(r=0.62)$ in spring and summer $(n=$ 10) are statistically significant $(p \leq 0.05)$. Furthermore, it showed a positive Spearman's rank correlation with isoprene SOA tracers $(r=0.33)$ and $\beta$-caryophylinic acid $(r=0.37)$. However, WSON shows no relation with sucrose, isopreneand $\alpha$-pinene-SOA tracers, $\beta$-caryophylinic acid and $\mathrm{MSA}^{-}$ 
Table 3. Spearman's rank correlation of WSON and WION with source tracers in Sapporo aerosols during the study period $(n=21)$. Significant correlation coefficients at 0.05 level are shown in bold.

\begin{tabular}{lrr}
\hline \multirow{2}{*}{ Source tracer } & \multicolumn{2}{c}{ Correlation coefficient $(r)$} \\
\cline { 2 - 3 } & WSON & WION \\
\hline Hopanes & $\mathbf{0 . 4 8}$ & $\mathbf{- 0 . 5 0}$ \\
Levoglucosan & 0.18 & $\mathbf{- 0 . 5 7}$ \\
Sucrose & -0.02 & $\mathbf{0 . 3 8}$ \\
Isoprene-SOA tracers & -0.12 & $\mathbf{0 . 5 0}$ \\
$\alpha$-pinene-SOA tracers & 0.21 & 0.14 \\
$\beta$-caryophylinic acid & 0.06 & 0.30 \\
MSA $^{-}$ & 0.09 & $\mathbf{0 . 5 9}$ \\
\hline
\end{tabular}

when we consider the total data set $(n=21)$, which includes all seasons during the campaign (Table 3 ).

The above comparisons of WSON with source tracers imply that anthropogenic emissions including biomass burning are major sources of WSON in Sapporo aerosols. Their contributions to Sapporo aerosols may have been enhanced in autumn and winter when the air masses enriched with forest fire and fossil fuel combustion products are often delivered from Siberia, passing over northeastern China (Fig. 1a, b). In fact, fossil fuel consumption is significantly higher in winter than in any other season in eastern Asia (Zhang et al., 2009). Furthermore, emissions of biological particles and secondary production by the reaction of biogenic hydrocarbons with $\mathrm{NO}_{3}$ radicals (Fry et al., 2009; Pratt et al., 2012) could contribute to WSON in late spring and late spring or early autumn, respectively, although we do not preclude a minor contribution from biomass burning emissions. In fact, levels of $\mathrm{NO}_{3}^{-}$in Sapporo aerosols declined in late spring to summer followed by a gradual increase toward early autumn (Pavuluri et al., 2015). The lower levels of $\mathrm{NO}_{3}^{-}$in summer may be in part caused by $\mathrm{NO}_{3}^{-}$active involvement in the reactions with hydrocarbons (Fry et al., 2009; Pratt et al., 2012; Rollins et al., 2009) to result in secondary WSON, although clean air masses from oceanic regions often arrive in Sapporo during summer (Fig. 1d).

\subsubsection{Possible source and formation processes of WION}

The results of Spearman's rank correlation analysis between WION and source tracers are presented in Table 3. WION shows a significant inverse correlation with hopanes and levoglucosan during the campaign (Table 3). By contrast, the temporal trend in WION is similar to those of sucrose (Fig. 4e) during late spring to early summer and of biogenic SOA tracers (isoprene- and $\alpha$-pinene-SOA tracers and $\beta$ caryophyllinic acid, (Fig. 4f) and $\mathrm{MSA}^{-}$; Fig. 4g) throughout the year. Furthermore, WION showed a moderately significant positive Spearman's correlation with sucrose, isoprene SOA and $\mathrm{MSA}^{-}$during the study period $(n=21)$ (Table 3 ) and also with $\beta$-caryophyllinic acid in spring and summer $(r=0.62, p \leq 0.05 ; n=10)$.

Based on the above comparisons of WION with source tracers, we suggest that the WION in Sapporo aerosols is mainly derived from emissions of biological particles such as pollens and from secondary production by the reactions of biogenic hydrocarbons (containing carbonyls) with $\mathrm{NH}_{3}$ in the atmosphere (Bones et al., 2010; Updyke et al., 2012). WSON could be abundantly produced if the oxidation of biogenic hydrocarbons by $\mathrm{NO}_{3}$ radicals were prominent. However, the SOA preferably produced by $\mathrm{O}_{3}$-initiated oxidation of biogenic hydrocarbons (e.g., isoprene and monoterpenes) contains carbonyl groups that can react with reduced nitrogen species such as $\mathrm{NH}_{3}(\mathrm{~g}), \mathrm{NH}_{4}^{+}$and amino acids and produce high-molecular-weight $\mathrm{N}$-containing organics (Bones et al., 2010; Updyke et al., 2012), which may not be fully water-soluble. For example, glyoxal has been reported to form an imidazole (Galloway et al., 2009) and also undergo oligomerization reactions (Noziere et al., 2009) to form highmolecular-weight $\mathrm{N}$-containing organics in the presence of $\mathrm{NH}_{3}$. In fact, Wang et al. (2010) observed high-molecularweight N-containing organic salts $(m / z$ range of $250-500)$ at substantial intensities in the positive-ion mass spectra in urban aerosols from Shanghai, China. They interpreted such high-molecular-weight organic salts formation by Mannich reaction rather than the oligomerization of imidazole alone.

Based on observations under controlled environmental conditions, Husted and Schjoerring (1996) reported that $\mathrm{NH}_{3}$ emission from plants is enhanced with increasing leaf temperature and light intensity, which is similar to the emission of organic compounds from higher plants (Guenther, 1997). On the other hand, the net emission of $\mathrm{NH}_{3}$ from soil is enhanced in summer due to increasing soil temperatures (Wentworth et al., 2014). Therefore, enhanced emissions of biogenic hydrocarbons and $\mathrm{NH}_{3}$ during the growing season (mid-spring to midsummer) are very likely in spring and summer followed by the subsequent reactions and production of WION in the atmosphere. In fact, the air masses arriving in Sapporo originate from Siberia in spring from oceanic regions and pass over the Japanese Honshu in summer (Fig. 1c, d). They should be enriched with the components derived from terrestrial and/or oceanic emissions. In addition to biogenic SOA and $\mathrm{MSA}^{-}$(Fig. 4f, g), abundances of $\mathrm{NH}_{4}^{+}$are relatively high in spring and summer (Pavuluri et al., 2015). Hence, secondary production of WION by the reactions of SOA (carbonyls) with $\mathrm{NH}_{3}\left(\mathrm{NH}_{4}^{+} \leftrightarrow \mathrm{NH}_{3}\right)$ (Noziere et al., 2009) should be accelerated during the warmer seasons in northeastern Asia. However, there is a need to conduct measurements of WION and source tracers at different locations in order to fully understand the main source(s) of WION in atmospheric aerosols, which is a subject of future research. 


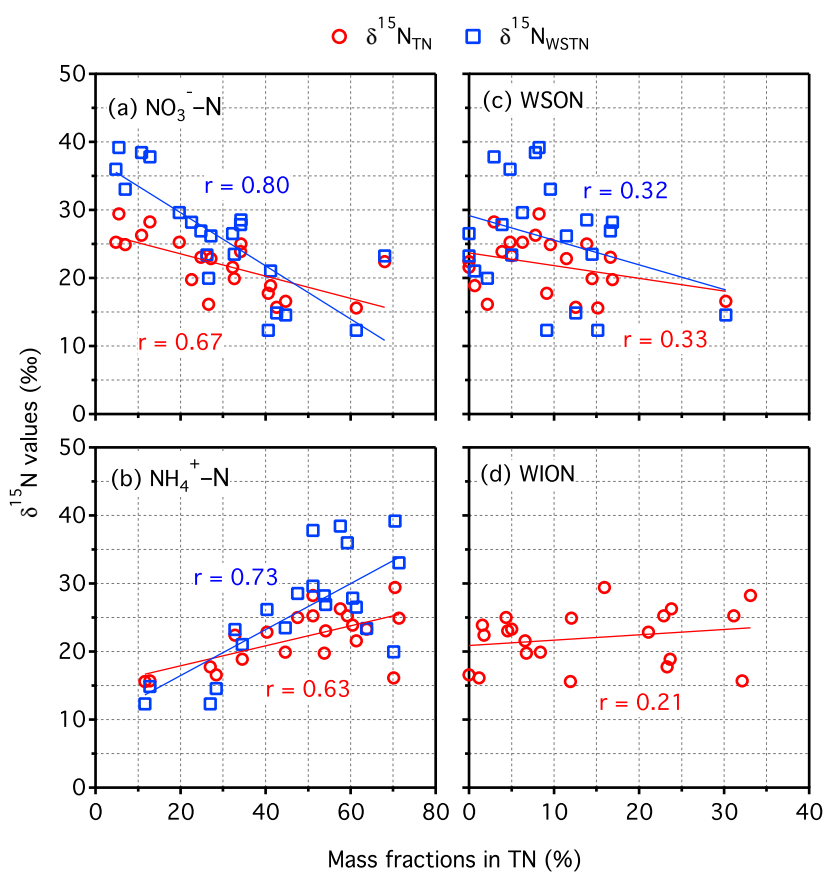

Figure 6. Scatterplots between $\delta^{15} \mathrm{~N}_{\mathrm{TN}}$ (and $\delta^{15} \mathrm{~N}_{\mathrm{WSTN}}$ ) and mass fractions of nitrogenous components $\left(\mathrm{NO}_{3}^{-}-\mathrm{N}, \mathrm{NH}_{4}^{+}-\mathrm{N}\right.$, WSON and WION) in TN in Sapporo aerosols.

\subsection{Nitrogen isotope ratios of TN and WSTN: implications for source and chemical aging}

\subsubsection{Seasonal variations}

$\delta^{15} \mathrm{~N}_{\mathrm{TN}}$ ranged from 15.5 to $29.4 \%$ (average $21.9 \pm 4.1 \%$ ), whereas $\delta^{15} \mathrm{~N}_{\text {WSTN }}$ ranged from 12.2 to $39.1 \%$ o (25.8 \pm $8.2 \%$ ) in Sapporo aerosols during the campaign period $(n=$ 21). As shown in Fig. 2b, temporal trends in $\delta^{15} \mathrm{~N}_{\mathrm{TN}}$ and $\delta^{15} \mathrm{~N}_{\text {WSTN }}$ were highly comparable. They both show peaks in summer with relatively high values in late autumn (Fig. 2b). Their averages, except for $\delta^{15} \mathrm{~N}_{\mathrm{TN}}$ in autumn and winter, varied significantly from season to season with higher $\delta^{15} \mathrm{~N}$ values in summer, followed by spring, winter and autumn (Table 1). The seasonal trends in $\delta^{15} \mathrm{~N}_{\mathrm{TN}}$ and $\delta^{15} \mathrm{~N}_{\mathrm{WSTN}}$ suggest that aerosol $\mathrm{N}$ is significantly influenced by season-specific source(s) and/or the chemical aging of $\mathrm{N}$ species.

We also found that $\delta^{15} \mathrm{~N}_{\text {WSTN }}$ is higher than $\delta^{15} \mathrm{~N}_{\mathrm{TN}}$ throughout the campaign, except for few samples in autumn (Fig. 2b). An enrichment of ${ }^{15} \mathrm{~N}$ in WSTN over TN is more significant in summer than in other seasons (Table 1). It has been reported that the aerosol particles collected over controlled laboratory burns of the vegetation, which significantly contribute to WSTN, are enriched with ${ }^{15} \mathrm{~N}$ ranging from -1.3 to $13.1 \%$ (average $6.6 \%$ ) compared to the source vegetation (Turekian et al., 1998). Furthermore, chemical aging of $\mathrm{N}$ species, including gas-to-particle exchange (e.g., $\mathrm{NH}_{4}^{+} \leftrightarrow \mathrm{NH}_{3}$ ) reactions during long-range transport causes

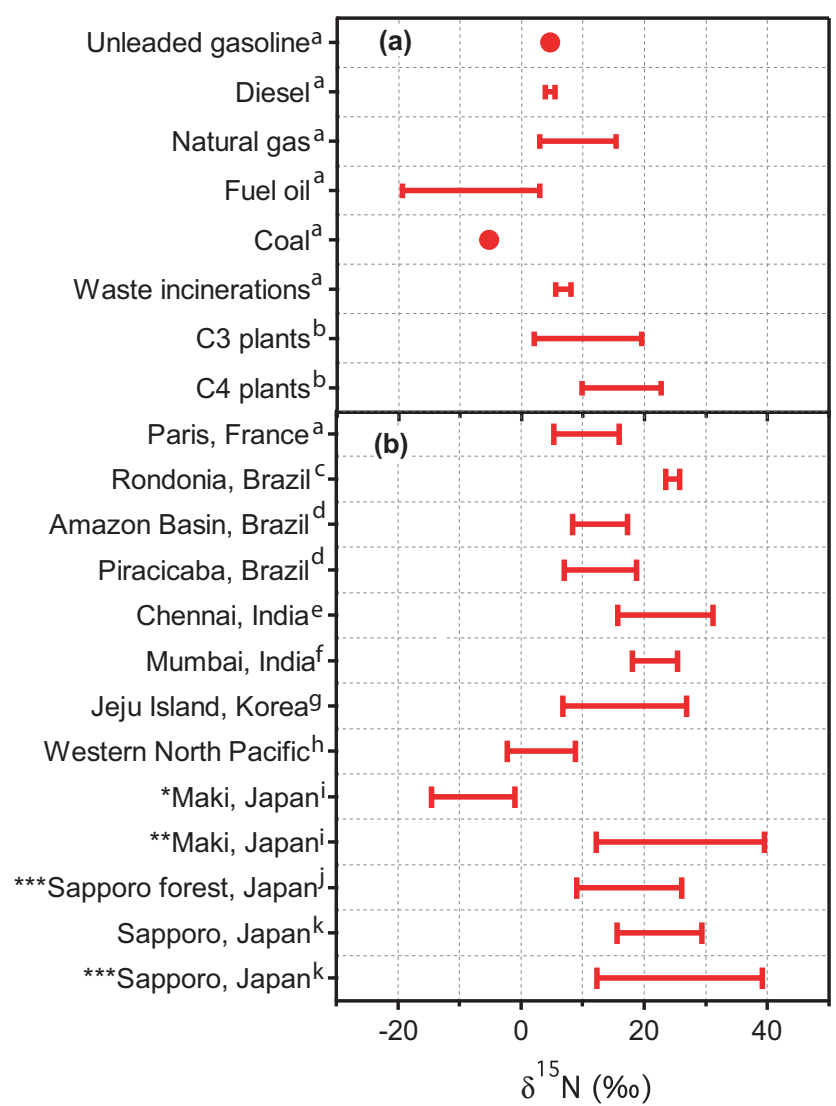

Figure 7. Range or mean $\mathrm{N}$ isotope ratios in the particles emitted from point sources, source substance, and atmospheric aerosols from different sites around the world. One, two and three asterisks show gaseous $\mathrm{NH}_{3}$, particulate $\mathrm{NH}_{4}^{+}$and WSTN, respectively. a Widory (2007); ${ }^{\mathrm{b}}$ Turekian et al. (1998); ${ }^{\mathrm{c}, \mathrm{g}}$ Kundu et al. (2010a, b); ${ }^{\mathrm{d}}$ Martinelli et al. (2002); ${ }^{\mathrm{e}}$ Pavuluri et al. (2010); ${ }^{\mathrm{f}}$ Aggarwal et al. (2013); h,j Miyazaki et al. (2011, 2014); ${ }^{\mathrm{i}}$ Hayasaka et al. (2004); $\mathrm{k}$ This study.

the enrichment of ${ }^{15} \mathrm{~N}$ in aerosol $\mathrm{N}$ (Pavuluri et al., 2010). In addition, $\delta^{15} \mathrm{~N}$ of terrestrial plants, which significantly contributes to WION, is relatively low (e.g., -3.4 to $12.2 \%$ o in plants from the San Francisco Bay area) (Cloern et al., 2002). Therefore, higher $\delta^{15} \mathrm{~N}_{\mathrm{WSTN}}$ values than $\delta^{15} \mathrm{~N}_{\mathrm{TN}}$ in Sapporo aerosols suggest that contributions of biomass burning to WSTN and biological sources to WION (i.e. TNWSTN) may be significant and aerosol $\mathrm{N}$ has been subjected to significant chemical aging during long-range transport. The enhanced aging (particularly $\mathrm{NH}_{4}^{+} \leftrightarrow \mathrm{NH}_{3}$ ) of nitrogenous aerosols under higher ambient temperature in summer may have caused further enrichment of ${ }^{15} \mathrm{~N}$ in WSTN (Pavuluri et al., 2010).

As seen from Fig. 6, $\delta^{15} \mathrm{~N}_{\mathrm{TN}}$ (and $\delta^{15} \mathrm{~N}_{\mathrm{WSTN}}$ ) showed an inverse relation with the mass fractions of $\mathrm{NO}_{3}^{-}-\mathrm{N}$ and WSON in TN but showed a linear relation with $\mathrm{NH}_{4}^{+}-\mathrm{N} / \mathrm{TN}$ and WION/TN during the study period. Their relations with $\mathrm{NO}_{3}^{-}-\mathrm{N} / \mathrm{TN}$ and $\mathrm{NH}_{4}^{+}-\mathrm{N} / \mathrm{TN}$ are statistically significant at 
the $99 \%(p \leq 0.01)$ level but not in the other two cases (Fig. 6). Such relations imply that $\delta^{15} \mathrm{~N}_{\mathrm{TN}}$ and $\delta^{15} \mathrm{~N}_{\mathrm{WSTN}}$ are mainly controlled by their sources, chemical aging of nitrogenous species and abundances of $\mathrm{NO}_{3}^{-}-\mathrm{N}$ and $\mathrm{NH}_{4}^{+}-\mathrm{N}$. It is well recognized that $\mathrm{NO}_{3}^{-}$originates mainly from fossil fuel combustion and biomass burning, whereas $\mathrm{NH}_{4}^{+}$originates from biomass burning, agricultural activities and biological emissions (Delon et al., 2012; Hertel et al., 2012). In fact, $\mathrm{NO}_{3}^{-}$is more abundant in mid-autumn to early spring, whereas $\mathrm{NH}_{4}^{+}$maximizes in mid-spring to summer (Pavuluri et al., 2015). These results are consistent with those of source tracers (Fig. 4), again suggesting that the contributions from biomass burning and fossil fuel combustion are important in autumn and winter, whereas the biological particles are important in spring and biogenic emissions of gaseous species (hydrocarbons and $\mathrm{NH}_{3}$ ) and subsequent secondary production are important in spring/summer.

\subsubsection{Comparison with literature values}

Figure 7 compares the range (or mean) of $\delta^{15} \mathrm{~N}$ values reported for the particles emitted from point sources in midlatitudes as well as those observed in atmospheric aerosols from different locations around the world, including Sapporo aerosols. $\delta^{15} \mathrm{~N}_{\mathrm{TN}}$ values observed in Sapporo aerosols are significantly higher than those ( -19.4 to $15.4 \%$ o) reported for the particles emitted from point sources of fossil fuel combustion and waste incineration burning (Fig. 7). They are also higher than those reported in urban aerosols from Paris, France, where fossil fuel combustion was expected as a major source (Widory, 2007), and the marine aerosols over the western North Pacific, which are considered to be mainly derived from sea-to-air emissions (Miyazaki et al., 2011) (Fig. 7).

However, $\delta^{15} \mathrm{~N}_{\mathrm{TN}}$ in Sapporo aerosols are comparable to the higher ends of the $\delta^{15} \mathrm{~N}_{\mathrm{TN}}$ reported in atmospheric aerosols from Jeju Island, Korea (Fig. 7), which were attributed to the significant atmospheric processing of $\mathrm{N}$ species, emitted mainly from China, during long-range transport (Kundu et al., 2010b). Furthermore, the lower ends of $\delta^{15} \mathrm{~N}_{\mathrm{TN}}$ in Sapporo aerosols are comparable to the higher ends of $\delta^{15} \mathrm{~N}_{\mathrm{TN}}$ reported for the particles emitted from the controlled burning of $\mathrm{C}_{3}$ (range, 2.0 to $19.5 \%$ ) and $\mathrm{C}_{4}(9.8$ to $22.7 \%$ o plant species in a laboratory study and to those of atmospheric aerosols from Piracicaba and the Amazon basin, Brazil, where biomass burning is a dominant source (Martinelli et al., 2002) (Fig. 7). In addition, they compare well to $\delta^{15} \mathrm{~N}_{\mathrm{TN}}$ reported in the forest aerosols from Rondônia, Brazil, where biomass burning was expected as a dominant source (Kundu et al., 2010a), and urban aerosols from Chennai and Mumbai, India, which were considered to mainly originate from biomass burning and to have been subjected to aging (Aggarwal et al., 2013; Pavuluri et al., 2010) (Fig. 7).

On the other hand, lower values of $\delta^{15} \mathrm{~N}_{\mathrm{WSTN}}$ observed in Sapporo aerosols are comparable to those reported in the forest aerosols from Sapporo experimental forest, Japan (Fig. 7). Although their seasonal patterns (winter minimum and summer maximum) are similar, the enrichment of ${ }^{15} \mathrm{~N}$ in Sapporo aerosols (Fig. 2b) is significantly higher than that (range of monthly averages: 9.0 to 26.0\%o) reported for the Sapporo forest aerosols (Miyazaki et al., 2014). Furthermore, the range of $\delta^{15} \mathrm{~N}_{\mathrm{WSTN}}$ values observed in Sapporo aerosols is highly comparable to $\delta^{15} \mathrm{~N}$ of aerosol $\mathrm{NH}_{4}^{+}$, which is much higher than that of gaseous $\mathrm{NH}_{3}$, in the atmosphere measured at the Maki monitoring station, Niigata, Japan (Fig. 7). The large difference in $\delta^{15} \mathrm{~N}$ between $\mathrm{NH}_{3}$ and $\mathrm{NH}_{4}^{+}$has been attributed to gas-to-particle (equilibrium) exchange reactions in the atmosphere (Hayasaka et al., 2004) because under equilibrium conditions, particulate $\mathrm{NH}_{4}^{+}$is more enriched with ${ }^{15} \mathrm{~N}$ than gaseous $\mathrm{NH}_{3}$, where the isotopic enrichment

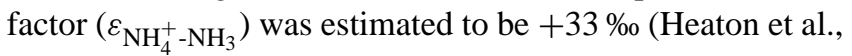
1997). Such comparisons suggest that aerosol N in Sapporo aerosols might have originated to a significant extent from biogenic sources, including biomass burning, and subjected to chemical aging during long-range transport, although we do not preclude a contribution from fossil fuel combustion.

\section{Summary and conclusions}

Water-soluble organic nitrogen (WSON) and water-insoluble organic nitrogen (WION) and $\mathrm{N}$ isotope ratios of total nitrogen $\left(\delta^{15} \mathrm{~N}_{\mathrm{TN}}\right)$ and water-soluble TN $\left(\delta^{15} \mathrm{~N}_{\mathrm{WSTN}}\right)$ were obtained for TSP aerosol samples collected from Sapporo, northern Japan, from September 2009 to October 2010. WSON and WION ranged from BDL to $288 \mathrm{ng} \mathrm{m}^{-3}$ (average $89.7 \pm 80.6 \mathrm{ngm}^{-3}$ ) and from BDL to $454 \mathrm{ng} \mathrm{m}^{-3}$ $\left(126 \pm 117 \mathrm{ng} \mathrm{m}^{-3}\right)$. Although their temporal variations did not show clear seasonal trends, average WSON was found to be higher in winter, followed by autumn, spring and summer, whereas WION maximized in summer followed by spring, with much lower concentration in autumn and winter. $\delta^{15} \mathrm{~N}_{\mathrm{TN}}$ ranged from 15.5 to $29.4 \%$ (average $21.9 \pm 4.1 \%$ ), whereas $\delta^{15} \mathrm{~N}_{\text {WSTN }}$ ranged from 12.2 to $39.1 \%$ (25.8土 $8.2 \%$ ). Their seasonal variations showed high ratios in summer and late autumn. Comparisons of seasonal variations in WSON and WION with anthropogenic and biological source tracers together with air mass trajectories suggest that fossil fuel combustion and biomass burning are major sources of WSON, whereas emissions of biological particles and secondary reactions of biogenic hydrocarbons (carbonyls) with $\mathrm{NH}_{3}$ significantly contribute to WION in northeastern Asia. Seasonal variations in $\delta^{15} \mathrm{~N}_{\mathrm{TN}}$ and $\delta^{15} \mathrm{~N}_{\mathrm{WSTN}}$ and their relations to mass fractions of nitrogenous components in $\mathrm{TN}$ suggest that aerosol $\mathrm{N}$ in Sapporo aerosols mainly originated from biogenic sources, including biomass burning, and was subjected to chemical aging during long-range transport, although a contribution from fossil fuel combustion is important particularly in winter. 
Acknowledgements. This study was in part supported by Japan Society for the Promotion of Science (Grant-in-Aid nos. 1920405 and 24221001) and the Environment Research and Technology Development Fund (B903) of the Ministry of the Environment, Japan.

Edited by: A. B. Guenther

\section{References}

Aggarwal, S. G. and Kawamura, K.: Molecular distributions and stable carbon isotopic compositions of dicarboxylic acids and related compounds in aerosols from Sapporo, Japan: Implications for photochemical aging during long-range atmospheric transport, J. Geophys. Res.-Atmos., 113, D14301, doi:10.1029/2007JD009365, 2008.

Aggarwal, S. G., Kawamura, K., Umarji, G. S., Tachibana, E., Patil, R. S., and Gupta, P. K.: Organic and inorganic markers and stable $\mathrm{C}$-, $\mathrm{N}$-isotopic compositions of tropical coastal aerosols from megacity Mumbai: sources of organic aerosols and atmospheric processing, Atmos. Chem. Phys., 13, 4667-4680, doi:10.5194/acp-13-4667-2013, 2013.

Bates, T. S., Calhoun, J. A., and Quinn, P. K.: Variations in the Methanesulfonate to Sulfate Molar Ratio in Submicrometer Marine Aerosol-Particles over the South-Pacific Ocean, J. Geophys. Res.-Atmos., 97, 9859-9865, 1992.

Bones, D. L., Henricksen, D. K., Mang, S. A., Gonsior, M., Bateman, A. P., Nguyen, T. B., Cooper, W. J., and Nizkorodov, S. A.: Appearance of strong absorbers and fluorophores in limonene$\mathrm{O} 3$ secondary organic aerosol due to $\mathrm{NH}_{4}^{+}$-mediated chemical aging over long time scales, J. Geophys. Res.-Atmos., 115, D05203, doi:10.1029/2009JD012864, 2010.

Cape, J. N., Cornell, S. E., Jickells, T. D.. and Nemitz, E.: Organic nitrogen in the atmosphere - Where does it come from? A review of sources and methods, Atmos. Res., 102, 30-48, 2011.

Cloern, J. E., Canuel, E. A., and Harris, D.: Stable carbon and nitrogen isotope composition of aquatic and terrestrial plants of the San Francisco Bay estuarine system, Limnol. Oceanogr., 47, 713-729, 2002.

Cornell, S., Mace, K., Coeppicus, S., Duce, R., Huebert, B., Jickells, T., and Zhuang, L. Z.: Organic nitrogen in Hawaiian rain and aerosol, J. Geophys. Res.-Atmos., 106, 7973-7983, 2001.

Delon, C., Galy-Lacaux, C., Adon, M., Liousse, C., Serça, D., Diop, B., and Akpo, A.: Nitrogen compounds emission and deposition in West African ecosystems: comparison between wet and dry savanna, Biogeosciences, 9, 385-402, doi:10.5194/bg-9-385-2012, 2012.

Dentener, F., Drevet, J., Lamarque, J. F., Bey, I., Eickhout, B., Fiore, A. M., Hauglustaine, D., Horowitz, L. W., Krol, M., Kulshrestha, U. C., Lawrence, M., Galy-Lacaux, C., Rast, S., Shindell, D., Stevenson, D., Van Noije, T., Atherton, C., Bell, N., Bergman, D., Butler, T., Cofala, J., Collins, B., Doherty, R., Ellingsen, K., Galloway, J., Gauss, M., Montanaro, V., Muller, J. F., Pitari, G., Rodriguez, J., Sanderson, M., Solmon, F., Strahan, S., Schultz, M., Sudo, K., Szopa, S., and Wild, O.: Nitrogen and sulfur deposition on regional and global scales: A multimodel evaluation, Global Biogeochem. Cy., 20, GB4003, doi:10.1029/2005gb002672, 2006.
Draxler, R. R. and Rolph, G. D.: HYSPLIT (HYbrid SingleParticle Lagrangian Integrated Trajectory) Model access via NOAA ARL READY Website, NOAA Air Resources Laboratory, Silver Spring, MD, available at: http://ready.arl.noaa.gov/ HYSPLIT.php (last access: 20 January 2011), 2012.

Duce, R. A., LaRoche, J., Altieri, K., Arrigo, K. R., Baker, A. R., Capone, D. G., Cornell, S., Dentener, F., Galloway, J., Ganeshram, R. S., Geider, R. J., Jickells, T., Kuypers, M. M., Langlois, R., Liss, P. S., Liu, S. M., Middelburg, J. J., Moore, C. M., Nickovic, S., Oschlies, A., Pedersen, T., Prospero, J., Schlitzer, R., Seitzinger, S., Sorensen, L. L., Uematsu, M., U1loa, O., Voss, M., Ward, B., and Zamora, L.: Impacts of atmospheric anthropogenic nitrogen on the open ocean, Science, 320, 893-897, 2008.

Fry, J. L., Kiendler-Scharr, A., Rollins, A. W., Wooldridge, P. J., Brown, S. S., Fuchs, H., Dubé, W., Mensah, A., dal Maso, M., Tillmann, R., Dorn, H.-P., Brauers, T., and Cohen, R. C.: Organic nitrate and secondary organic aerosol yield from $\mathrm{NO}_{3}$ oxidation of $\beta$-pinene evaluated using a gas-phase kinetics/aerosol partitioning model, Atmos. Chem. Phys., 9, 14311449, doi:10.5194/acp-9-1431-2009, 2009.

Fu, P. Q., Kawamura, K., Pavuluri, C. M., Swaminathan, T., and Chen, J.: Molecular characterization of urban organic aerosol in tropical India: contributions of primary emissions and secondary photooxidation, Atmos. Chem. Phys., 10, 2663-2689, doi:10.5194/acp-10-2663-2010, 2010.

Fu, P. Q., Kawamura, K., Kobayashi, M., and Simoneit, B. R. T.: Seasonal variations of sugars in atmospheric particulate matter from Gosan, Jeju Island: Significant contributions of airborne pollen and Asian dust in spring, Atmos. Environ., 55, 234-239, 2012.

Galloway, J. N., Dentener, F. J., Capone, D. G., Boyer, E. W., Howarth, R. W., Seitzinger, S. P., Asner, G. P., Cleveland, C. C., Green, P. A., Holland, E. A., Karl, D. M., Michaels, A. F., Porter, J. H., Townsend, A. R., and Vorosmarty, C. J.: Nitrogen cycles: past, present, and future, Biogeochemistry, 70, 153-226, 2004.

Galloway, M. M., Chhabra, P. S., Chan, A. W. H., Surratt, J. D., Flagan, R. C., Seinfeld, J. H., and Keutsch, F. N.: Glyoxal uptake on ammonium sulphate seed aerosol: reaction products and reversibility of uptake under dark and irradiated conditions, Atmos. Chem. Phys., 9, 3331-3345, doi:10.5194/acp-9-3331-2009, 2009.

Geng, C. M. and Mu, Y. J.: Carbonyl sulfide and dimethyl sulfide exchange between trees and the atmosphere, Atmos. Environ., 40, 1373-1383, 2006.

Guenther, A.: Seasonal and spatial variations in natural volatile organic compound emissions, Ecol. Appl., 7, 34-45, 1997.

Hayasaka, H., Fukuzaki, N., Kondo, S., Ishizuka, T., and Totsuka, T.: Nitrogen isotopic ratios of gaseous ammonia and ammonium aerosols in the atmosphere, J. Jpn. Soc. Atmos. Environ., 39, 272-279, 2004 (in Japanese).

Heaton, T. H. E., Spiro, B., Madeline, S., and Robertson, C.: Potential canopy influences on the isotopic composition of nitrogen and sulphur in atmospheric deposition, Oecologia, 109, 600-607, doi:10.1007/S004420050122, 1997.

Hertel, O., Skjøth, C. A., Reis, S., Bleeker, A., Harrison, R. M., Cape, J. N., Fowler, D., Skiba, U., Simpson, D., Jickells, T., Kulmala, M., Gyldenkærne, S., Sørensen, L. L., Erisman, J. W., and Sutton, M. A.: Governing processes for reactive nitrogen com- 
pounds in the European atmosphere, Biogeosciences, 9, 49214954, doi:10.5194/bg-9-4921-2012, 2012.

Hoefs, J.: Stable isotope geochemistry, 6th Edition, Springer, Berlin, 2009.

Hoffmann, D., Tilgner, A., Iinuma, Y., and Herrmann, H.: Atmospheric stability of levoglucosan: a detailed laboratory and modeling study, Environ. Sci. Technol., 44, 694-699, 2010.

Husted, S. and Schjoerring, J. K.: Ammonia flux between oilseed rape plants and the atmosphere in response to changes in leaf temperature, light intensity, and air humidity - Interactions with leaf conductance and apoplastic $\mathrm{NH}_{4}^{+}$and $\mathrm{H}^{+}$concentrations, Plant Physiol., 112, 67-74, 1996.

Jickells, T., Baker, A. R., Cape, J. N., Cornell, S. E., and Nemitz, E.: The cycling of organic nitrogen through the atmosphere, Philos. T. R. Soc. B., 368, 20130115, doi:10.1098/Rstb.2013.0115, 2013.

Kanakidou, M., Duce, R. A., Prospero, J. M., Baker, A. R., BenitezNelson, C., Dentener, F. J., Hunter, K. A., Liss, P. S., Mahowald, N., Okin, G. S., Sarin, M., Tsigaridis, K., Uematsu, M., Zamora, L. M., and Zhu, T.: Atmospheric fluxes of organic N and $\mathrm{P}$ to the global ocean, Global Biogeochem. Cy., 26, GB3026, doi:10.1029/2011GB004277, 2012.

Kawamura, K., Kosaka, M., and Sempéré, R.: Distributions and seasonal changes of hydrocarbons in urban aerosols and rainwaters, Chikyukagaku (Geochemistry), 29, 1-15, 1995.

Kawamura, K., Kobayashi, M., Tsubonuma, N., Mochida, M., Watanabe, T., and Lee, M., Organic and inorganic compositions of marine aerosols from East Asia: Seasonal variations of watersoluble dicarboxylic acids, major ions, total carbon and nitrogen, and stable $\mathrm{C}$ and $\mathrm{N}$ isotopic composition, in: Geochemical Investigations in Earth and Space Science: A Tribute to Isaac R. Kaplan, edited by: Hill, R. J., Leventhal, J., Aizenshtat, Z., Baedecker, M. J., Claypool, G., Eganhouse, R., Goldhaber, M., and Peters, K., The Geochemical Society, Publication No. 9, Saint Louis, MO, USA, 2004.

Kim, T. W., Lee, K., Duce, R., and Liss, P.: Impact of atmospheric nitrogen deposition on phytoplankton productivity in the South China Sea, Geophys. Res. Lett., 41, 3156-3162, 2014.

Kleindienst, T. E., Jaoui, M., Lewandowski, M., Offenberg, J. H., Lewis, C. W., Bhave, P. V., and Edney, E. O.: Estimates of the contributions of biogenic and anthropogenic hydrocarbons to secondary organic aerosol at a southeastern US location, Atmos. Environ., 41, 8288-8300, 2007.

Kundu, S., Kawamura, K., Andreae, T. W., Hoffer, A., and Andreae, M. O.: Diurnal variation in the water-soluble inorganic ions, organic carbon and isotopic compositions of total carbon and nitrogen in biomass burning aerosols from the LBA-SMOCC campaign in Rondonia, Brazil, J. Aerosol Sci., 41, 118-133, doi:10.1016/j.jaerosci.2009.08.006, 2010a.

Kundu, S., Kawamura, K., and Lee, M.: Seasonal variation of the concentrations of nitrogenous species and their nitrogen isotopic ratios in aerosols at Gosan, Jeju Island: Implications for atmospheric processing and source changes of aerosols, J. Geophys. Res.-Atmos., 115, D20305, doi:10.1029/2009jd013323, 2010 b.

Laskin, A., Smith, J. S., and Laskin, J.: Molecular Characterization of Nitrogen-Containing Organic Compounds in Biomass Burning Aerosols Using High-Resolution Mass Spectrometry, Environ. Sci. Technol., 43, 3764-3771, 2009.
Liu, X. J., Zhang, Y., Han, W. X., Tang, A. H., Shen, J. L., Cui, Z. L., Vitousek, P., Erisman, J. W., Goulding, K., Christie, P., Fangmeier, A., and Zhang, F. S.: Enhanced nitrogen deposition over China, Nature, 494, 459-462, 2013.

Mace, K. A., Artaxo, P., and Duce, R. A.: Water-soluble organic nitrogen in Amazon Basin aerosols during the dry (biomass burning) and wet seasons, J. Geophys. Res.-Atmos., 108, 4512, doi:10.1029/2003JD003557, 2003a.

Mace, K. A., Duce, R. A., and Tindale, N. W.: Organic nitrogen in rain and aerosol at Cape Grim, Tasmania, Australia, J. Geophys. Res.-Atmos., 108, 4338, doi:10.1029/2002JD003051, 2003 b.

Mace, K. A., Kubilay, N., and Duce, R. A.: Organic nitrogen in rain and aerosol in the eastern Mediterranean atmosphere: An association with atmospheric dust, J. Geophys. Res.-Atmos., 108, 4320, doi:10.1029/2002/JD002997, 2003c.

Martinelli, L. A., Camargo, P. B., Lara, L. B. L. S., Victoria, R. L., and Artaxo, P.: Stable carbon and nitrogen isotopic composition of bulk aerosol particles in a $\mathrm{C}_{4}$ plant landscape of southeast Brazil, Atmos. Environ., 36, 2427-2432, 2002.

Matsumoto, K., Yamamoto, Y., Kobayashi, H., Kaneyasu, N., and Nakano, T.: Water-soluble organic nitrogen in the ambient aerosols and its contribution to the dry deposition of fixed nitrogen species in Japan, Atmos. Environ., 95, 334-343, 2014.

Miyazaki, Y., Kawamura, K., Jung, J., Furutani, H., and Uematsu, M.: Latitudinal distributions of organic nitrogen and organic carbon in marine aerosols over the western North Pacific, Atmos. Chem. Phys., 11, 3037-3049, doi:10.5194/acp-11-3037-2011, 2011.

Miyazaki, Y., Fu, P. Q., Ono, K., Tachibana, E., and Kawamura, K.: Seasonal cycles of water-soluble organic nitrogen aerosols in a deciduous broadleaf forest in northern Japan, J. Geophys. Res.Atmos., 119, 1440-1454, 2014.

Morino, Y., Ohara, T., Kurokawa, J., Kuribayashi, M., Uno, I., and Hara, H.: Temporal variations of nitrogen wet deposition across Japan from 1989 to 2008, J. Geophys. Res.-Atmos., 116, D06307, doi:10.1029/2010JD015205, 2011.

Nakamura, T., Ogawa, H., Maripi, D. K., and Uematsu, M.: Contribution of water soluble organic nitrogen to total nitrogen in marine aerosols over the East China Sea and western North Pacific, Atmos. Environ., 40, 7259-7264, 2006.

Neff, J. C., Holland, E. A., Dentener, F. J., McDowell, W. H., and Russell, K. M.: The origin, composition and rates of organic nitrogen deposition: A missing piece of the nitrogen cycle?, Biogeochemistry, 57, 99-136, 2002.

Neiuwenhuize, J., Mass, Y. E. M., and Middelburg, J. J.: Rapid analysis of organic carbon and nitrogen in particulate materials, Marine Chem., 45, 217-224, 1994.

Noziere, B., Dziedzic, P., and Cordova, A.: Products and Kinetics of the Liquid-Phase Reaction of Glyoxal Catalyzed by Ammonium Ions $\left(\mathrm{NH}_{4}^{+}\right)$, J. Phys. Chem. A, 113, 231-237, 2009.

Pavuluri, C. M., Kawamura, K., Tachibana, E., and Swaminathan, T.: Elevated nitrogen isotope ratios of tropical Indian aerosols from Chennai: Implication for the origins of aerosol nitrogen in South and Southeast Asia, Atmos. Environ., 44, 3597-3604, doi:10.1016/J.Atmosenv.2010.05.039, 2010.

Pavuluri, C. M., Kawamura, K., Uchida, M., Kondo, M., and Fu, P. Q.: Enhanced modern carbon and biogenic organic tracers in Northeast Asian aerosols during spring/summer, J. Geophys. Res.-Atmos., 118, 2362-2371, 2013. 
Pavuluri, C. M., Kawamura, K., Mihalopoulos, N., and Fu, P. Q.: Characteristics, seasonality and sources of inorganic ions and trace metals in Northeast Asian aerosols, Environ. Chem., 12, 338-349, 2015.

Pratt, K. A., Mielke, L. H., Shepson, P. B., Bryan, A. M., Steiner, A. L., Ortega, J., Daly, R., Helmig, D., Vogel, C. S., Griffith, S., Dusanter, S., Stevens, P. S., and Alaghmand, M.: Contributions of individual reactive biogenic volatile organic compounds to organic nitrates above a mixed forest, Atmos. Chem. Phys., 12, 10125-10143, doi:10.5194/acp-12-10125-2012, 2012.

Rollins, A. W., Kiendler-Scharr, A., Fry, J. L., Brauers, T., Brown, S. S., Dorn, H.-P., Dubé, W. P., Fuchs, H., Mensah, A., Mentel, T. F., Rohrer, F., Tillmann, R., Wegener, R., Wooldridge, P. J., and Cohen, R. C.: Isoprene oxidation by nitrate radical: alkyl nitrate and secondary organic aerosol yields, Atmos. Chem. Phys., 9, 6685-6703, doi:10.5194/acp-9-6685-2009, 2009.

Rollins, A. W., Browne, E. C., Min, K. E., Pusede, S. E., Wooldridge, P. J., Gentner, D. R., Goldstein, A. H., Liu, S., Day, D. A., Russell, L. M., and Cohen, R. C.: Evidence for NOx Control over Nighttime SOA Formation, Science, 337, 1210-1212, 2012.

Russell, K. M., Keene, W. C., Maben, J. R., Galloway, J. N., and Moody, J. L.: Phase partitioning and dry deposition of atmospheric nitrogen at the mid-Atlantic US coast, J. Geophys. Res.Atmos., 108, 4656, doi:10.1029/2003JD003736, 2003.

Schaap, M., Spindler, G., Schulz, M., Acker, K., Maenhaut, W., Berner, A., Wieprecht, W., Streit, N., Muller, K., Bruggemann, E., Chi, X., Putaud, J. P., Hitzenberger, R., Puxbaum, H., Baltensperger, U., and ten Brink, H.: Artefacts in the sampling of nitrate studied in the "INTERCOMP" campaigns of EUROTRACAEROSOL, Atmos. Environ., 38, 6487-6496, 2004.

Schauer, J. J., Kleeman, M. J., Cass, G. R., and Simoneit, B. R. T.: Measurement of emissions from air pollution sources. 5. C1C32 organic compounds from gasoline-powered motor vehicles, Environ. Sci. Technol., 36, 1169-1180, 2002.

Shi, J. H., Gao, H. W., Qi, J. H., Zhang, J., and Yao, X. H.: Sources, compositions, and distributions of water-soluble organic nitrogen in aerosols over the China Sea, J. Geophys. Res.-Atmos., 115, D17303, doi:10.1029/2009JD013238, 2010.

Simoneit, B. R. T.: Biomass burning - a review of organic tracers for smoke from incomplete combustion, Appl. Geochem., 17, 129$162,2002$.

Squizzato, S., Masiol, M., Brunelli, A., Pistollato, S., Tarabotti, E., Rampazzo, G., and Pavoni, B.: Factors determining the formation of secondary inorganic aerosol: a case study in the Po Valley (Italy), Atmos. Chem. Phys., 13, 1927-1939, doi:10.5194/acp13-1927-2013, 2013.

Toma, Y., Fernandez, F. G., Sato, S., Izumi, M., Hatano, R., Yamada, T., Nishiwaki, A., Bollero, G., and Stewart, J. R.: Carbon budget and methane and nitrous oxide emissions over the growing season in a Miscanthus sinensis grassland in Tomakomai, Hokkaido, Japan, Gcb Bioenergy, 3, 116-134, 2011.
Turekian, V. C., Macko, S., Ballentine, D., Swap, R. J., and Garstang, M.: Causes of bulk carbon and nitrogen isotopic fractionations in the products of vegetation burns: laboratory studies, Chem. Geol., 152, 181-192, 1998.

Updyke, K. M., Nguyen, T. B., and Nizkorodov, S. A.: Formation of brown carbon via reactions of ammonia with secondary organic aerosols from biogenic and anthropogenic precursors, Atmos. Environ., 63, 22-31, 2012.

Violaki, K. and Mihalopoulos, N.: Water-soluble organic nitrogen (WSON) in size-segregated atmospheric particles over the Eastern Mediterranean, Atmos. Environ., 44, 4339-4345, 2010.

Vitousek, P. M., Aber, J. D., Howarth, R. W., Likens, G. E., Matson, P. A., Schindler, D. W., Schlesinger, W. H., and Tilman, D. Human alteration of the global nitrogen cycle: Sources and consequences, Ecol. Appl., 7, 737-750, 1997.

Wang, X. F., Gao, S., Yang, X., Chen, H., Chen, J. M., Zhuang, G. S., Surratt, J. D., Chan, M. N., and Seinfeld, J. H.: Evidence for High Molecular Weight Nitrogen-Containing Organic Salts in Urban Aerosols, Environ. Sci. Technol., 44, 4441-4446, 2010.

Wentworth, G. R., Murphy, J. G., Gregoire, P. K., Cheyne, C. A. L., Tevlin, A. G., and Hems, R.: Soil-atmosphere exchange of ammonia in a non-fertilized grassland: measured emission potentials and inferred fluxes, Biogeosciences, 11, 5675-5686, doi:10.5194/bg-11-5675-2014, 2014.

Widory, D.: Nitrogen isotopes: Tracers of origin and processes affecting $\mathrm{PM}_{10}$ in the atmosphere of Paris, Atmos. Environ., 41, 2382-2390, 2007.

Yamamoto, S., Kawamura, K., and Seki, O.: Long-range atmospheric transport of terrestrial biomarkers by the Asian winter monsoon: Evidence from fresh snow from Sapporo, northern Japan, Atmos. Environ., 45, 3553-3560, doi:10.1016/J.Atmosenv.2011.03.071, 2011.

Yi, Z. G., Wang, X. M., Ouyang, M. G., Zhang, D. Q., and Zhou, G. Y.: Air-soil exchange of dimethyl sulfide, carbon disulfide, and dimethyl disulfide in three subtropical forests in South China, J. Geophys. Res.-Atmos., 115, D18302, doi:10.1029/2010JD014130, 2010.

Zhang, Q., Anastasio, C., and Jimemez-Cruz, M.: Water-soluble organic nitrogen in atmospheric fine particles $\left(\mathrm{PM}_{2.5}\right)$ from northern California, J. Geophys. Res.-Atmos., 107, 4112, doi:10.1029/2001JD000870, 2002.

Zhang, Q., Streets, D. G., Carmichael, G. R., He, K. B., Huo, H., Kannari, A., Klimont, Z., Park, I. S., Reddy, S., Fu, J. S., Chen, D., Duan, L., Lei, Y., Wang, L. T., and Yao, Z. L.: Asian emissions in 2006 for the NASA INTEX-B mission, Atmos. Chem. Phys., 9, 5131-5153, doi:10.5194/acp-9-5131-2009, 2009.

Zhang, Y., Zheng, L. X., Liu, X. J., Jickells, T., Cape, J. N., Goulding, K., Fangmeier, A., and Zhang, F. S.: Evidence for organic N deposition and its anthropogenic sources in China, Atmos. Environ., 42, 1035-1041, 2008. 